\title{
So It Vanished: Art, Tapu and Shared Space in Contemporary Aotearoa New Zealand
}

\author{
Jonathan Barrett, Open Polytechnic, New Zealand
}

In February 2012, The Dowse Art Museum ('The Dowse') in Lower Hutt, New Zealand cancelled an exhibition by internationally renowned Mexican artist Teresa Margolles on the ostensible grounds of culture offence. This article analyses the cancellation of Margolles's So It Vanishes and situates it in the context of previous conflicts between Indigenous beliefs and exhibitions of transgressive art. Background information is firstly provided and Margolles's work is sketched and compared with other taboobreaking works of transgressive art. The Māori concept of tapu is then outlined. ${ }^{1}$ A discussion follows on the incompatibility of So It Vanishes with tapu, along with a review of other New Zealand exhibitions that have proved inconsistent with Indigenous values. Conclusions are then drawn about sharing exhibition space in contemporary Aotearoa NewZealand.

\section{Background}

\section{The Dowse}

The Dowse is situated in Lower Hutt, ${ }^{2}$ which has traditionally been a dormitory suburb for Wellington, but today is technically a city with an increasingly cosmopolitan population. In 2006, more than one fifth of residents were born outside New Zealand

\footnotetext{
${ }^{1}$ In this article, the words 'taboo,' 'tabu' and 'tapu' refer to Polynesian beliefs. Taboo, in roman font, refers to the Western adoption of the concept. The distinction lies between (literal) taboo and (figurative) taboo, the first and second definitions of 'taboo' provided in the Oxford English Dictionary (see Simpson \& Weiner 1989: 521).

${ }^{2}$ The Lower Hutt council has adopted the name 'Hutt City,' but this self-designation is not recognized by either the New Zealand Geographical Board or central government in the Local Government Act 2002. Referencing the Hutt River that reaches the sea at Petone (originally Pito-one), the Māori name for the area is Awakairangi (Maclean 2012). In email correspondence (10 April 2013), Ërima Hēnare, inter alia Chairman of Te Taura Whiri i te Reo The Māori Language Commission, advised that Te Atiawa understand Awakairangi as '[T]he river that consumes the sky.'
} 
(Hutt City Council 2007: 26). In contrast with the newcomer population, Indigenous people, who are principally associated with the Te Atiawa $i w i$ (tribe), ${ }^{3}$ constitute fifteen percent of residents (Hutt City Council 2007: 20). Despite its roots in local arts and crafts (Bell 2011), as a publicly funded institution The Dowse promotes itself as 'a dynamic institution which pairs an internationally recognized contemporary programme with meaningful community engagement' (The Dowse 2010). ${ }^{4}$ The Dowse is also custodian of various Māori taonga (treasures). Of particular note, the museum houses on permanent display and is kaitiaki (guardian) of Nuku Tewhatewha, an important pātaka (storehouse), which was 'constructed by the Ngati-Porou Tribe in 1856 for Wi Tako Ngatata, a Wellington district chief’ (Best 1916: 22). Such elaborately carved pātaka are 'rich in symbolism,' particularly with regard to chiefly prestige (see Neich 1996: 102-3), and may themselves carry the mana (prestige) of 'their former owners or makers' (Te Awekotuku 1996: 27). It is also noteworthy that Māori art is believed to have 'divine origins' (Mead 2003: 259). As well as permitting the museum to house such taonga, iwi perform ceremonial functions, such as blessing new public art, and have concluded a memorandum of understanding with Hutt City Council which provides for consultation on cultural issues. ${ }^{5}$

\section{So It Vanishes}

In December 2011, The Dowse announced that from 25 February 2012 until 17 June 2012 it would host an exhibition by acclaimed but controversial Mexican artist, Teresa Margolles, entitled So It Vanishes, as part of the Wellington-based, biennial New Zealand International Arts Festival (The Dowse 2011). Securing a work by Margolles, who represented Mexico in the 2009 Venice Biennale, was undoubtedly a major coup for a small, regional art museum, such as The Dowse, particularly since an attempt by

\footnotetext{
${ }^{3}$ In this article, translations of Māori words are taken from Williams (1992), Macalister (2005) or Ryan (2008), unless indicated otherwise. The term iwi refers to people holding mana whenua (power from and over land) in a particular area, notably Te Atiawa in relation to Awakairangi. Māori denotes the general Indigenous population. Following Metge (2010a: 60), Pākehā refers to all non-Māori since Māori tend to 'include all non-Māori when they couple Māori and Pākehā together in a single phrase.'

${ }^{4}$ The Dowse is principally funded through local rates. For the year ended 30 June 2011, Hutt City museums (The Dowse and the much smaller Petone Settlers Museum) earned revenue of less than NZ\$500,000 but, with operating costs in excess of NZ\$3 million, required a rates subsidy of around NZ\$2.5 million (Hutt City Council 2011: 71).

${ }^{5}$ The Port Nicholson Block Settlement Trust was established in August 2008 to receive and manage the settlement package for Taranaki Whanui ki Te Upoko o Te Ika (a collective comprising members of Te Atiawa and other Taranaki iwi whose ancestors migrated to the Wellington region): see The Port Nicholson Block (Taranaki Whanui ki Te Upoko o Te Ika) Claims Settlement Act 2009. The memorandum of understanding is between Hutt City Council and this trust.
} 
the Auckland Arts Triennial to exhibit Margolles's Lengua (Tongue) in 2004 was unsuccessful (see Burgess 2004). The planned installation comprised eight ceilingsituated machines dispensing bubbles into an empty, silent room. Over the 12 weeks of the exhibition, in what might be likened to a homeopathic degree of dilution, 20 millilitres of water previously used to wash corpses would be mixed with 260 litres of bubble solution (Dastgheib 2012: A3). Similar exhibitions had been staged in Brisbane, Frankfurt, Liverpool, Los Angeles and Zurich.

It is likely that Margolles's work would not have been well-known to many visitors to The Dowse. However a media release explained that the exhibition employed morgue water and included a link to Coulson (2004), an article that discusses the challenging nature of the artist's work. In terms that might be interpreted as braggadocio, it was also announced that 'just for The Dowse, a series of abstract portraits of the dead, containing a similar essence of run-off water and blood, will be displayed on a billboard outside the gallery' (The Dowse 2011). The media release did not receive significant publicity. ${ }^{6}$ Conversely, the newsletter distributed to friends of the museum spoke only of 'a scene of unearthly beauty that is underscored by a sense of unease' (Stephenson 2012: 4). Likewise, the widely distributed season brochure did not mention morgue water and merely described how Margolles ‘delicately deals with violence and death' (The Dowse 2012). Indeed, the cover for the season brochure featured a photograph of a similar installation, En el aire (In the Air), which was exhibited in Zurich in 2003. In the foreground, a woman contemplates the source of the bubbles; her expression appears serene, certainly not shocked or disgusted. To one side, a man's hand reaches out to catch a falling bubble, and, in the background, another woman is laughing, it seems, with delight. Since the key message of the media release was substantively different from that of the season brochure, it may be inferred that the extent to which people previously unaware of Margolles's work were forewarned of the true nature of So It Vanishes depended on the type of communication they received.

Amanda Coulson observes of Margolles's 2003 Frankfurt exhibition of En el Aire:

In the museum's soaring hall children play under bubbles ... Running, laughing, catching, they are fascinated by the glistening, delicate forms that float down from the ceiling and break up on their skin. A common motif in art history, the bubble has long been used as a memento mori, a reminder

\footnotetext{
${ }^{6}$ It appears that only Scoop Media, a news aggregator; the Manawatu Standard, a provincial newspaper; and the specialist magazine, Art News New Zealand, republished the media release.
} 
of the transitory nature of life. The children's parents, meanwhile, studiously read the captions. Suddenly, with a look of disgust, they come and steer their offspring away. The moment of naive pleasure turns into one of knowing repulsion: they have learned that the water comes from the Mexico City morgue, used to wash corpses before an autopsy. It's unimportant that the water is disinfected; the stigma of death turns the beautiful into the horrific. (2004)

Commenting on a similar installation in Brisbane, Greg Hooper says entering 'the room is to breathe in tiny little bits of the dead, molecules from the skin, watery homeopathic vibrations' (2007: 46), an experience that many visitors responded to with 'a cringing "yuck"" (Sorensen 2007). The sense of unease and queasiness that parents might experience on witnessing their children's exposure to morgue water, notwithstanding the infinitesimal traces in the bubbles, is radically different from the reaction of Māori. For them, such contact would be a breach of tapu, which is discussed below, and would genuinely imperil gallery-goers. When Sam Jackson, a Te Atiawa kaumātua (elder), was invited as a matter of normal protocol to bless this important exhibition, he declined. Jackson and the Port Nicholson Block Settlement Trust, which acts as the local iwi authority, sought to stop the exhibition on the grounds that it would be 'culturally unsafe' (Dastgheib 2012: A3). In the face of this opposition, Cam McCracken, director of The Dowse, announced the 'difficult' but 'important' decision to cancel the exhibition despite remaining 'utterly committed to the relevance and importance of [Margolles's] work' (2012).

\section{Margolles's work}

Before considering why So It Vanishes would have been offensive to Māori, Margolles's oeuvre is outlined. Coulson (2004) observes of the artist's first large-scale European solo exhibition:

Despite the show's title, 'Muerte sin fin' (Endless Death), death itself is not directly visually displayed; it is only in the viewer's psyche that the silent, minimal, often quite beautiful work is transformed into something appalling. In 'Aire' (Air, 2003) the viewer simply moves through a humid room; in 'Llorado' (Wept, 2004) water drips from the ceiling. In the former, it is the same disinfected morgue water moistening the room; in the latter, it is plain tap-water. We are appalled at the idea that we have absorbed the tincture of death.

So It Vanishes would have constituted a restrained piece relative to other examples of Margolles's work but may be situated in the Western tradition of taboo-breaking art. Rachel Spence (2009) describes how Margolles's Venice Biennale exhibition What Else Could We Talk About? used fabrics soaked with blood from Mexican drug war executions mopped up by volunteers and hung in the elegant salons of a Venetian 
palazzo. And Michael Nungesser outlines in the following terms some of her more controversial works:

\footnotetext{
'Lengua' (2000) consists of a killed youthful heroin addict's pierced tongue, which Margolla (sic) conserved and put on show. For the artistic use of this genuine body part, Margolles gave the bereaved family some money with which to bury the rest of the body. Then - as later in BerlinMargolles used human fat siphoned off in the anatomy institute in Mexico City, from which she had smuggled it. She smeared it onto public buildings in Cuba to 'restore' them ('Ciudad en espera,' Havana 2000). (2007)
}

Nungesser concludes that the artist 'touches taboos with her carefully dosed artistic transformations, spectacular and full of pathos. Her work with corpses handed over for autopsies draws attention to widespread anonymity and poverty, which does not allow bodies to be buried with dignity' (2007). In her review of Margolles's oeuvre, Rachel Scott Bray observes that 'the dead restlessly mingle, and there is no culturally convincing farewell to them and no alibi for us; there is no excuse for us not to pay attention' (2011: 946).

Treatment of dead bodies varies across cultures, but John Finnis is plausible when he argues that all cultures manifest valuing the human body through, inter alia, 'respectful disposal of the dead' (1980: 83). Margolles's point is that the rites and associated prohibitions of respectful disposal of the dead have been lost in the context of the slaughter that has beset certain parts of Mexico in its drug wars (see Grillo 2011). For many Mexican artists, such re-humanization of the countless victims of violence has, as Damien Cave observes, become an 'obsession: visualizing victimhood or, more broadly, turning cold, mind-numbing data back into real people' (2012: A6). Margolles does, however, express a singular and unorthodox way of respecting corpses. Smearing smuggled human fat on buildings, for instance, seems incompatible with any traditional manifestations of valuing the dead human body, despite her intention of restoring dignity to corpses. Indeed, for Rubén Gallo, her 'work can be read as an effort to draw attention to the breakdown of the taboo against corpses in Mexican society and to its dehumanizing effect' (2006: 126). Once presented with her arguments and motivations, a cosmopolitan gallery goer might well appreciate Margolles's intentions, albeit with vestigial discomfort. And shock is indubitably both intended and expected. Nevertheless, her political aim is to confront apparent indifference to quotidian human slaughter. Her art may engender distaste or disquiet, and it may break taboos, although once we understand her intention is to re-humanize those to whom dignity has been denied in 
both life and death, it may prompt political action. Indeed, 'her métier has been, simply put, the social and political economy of death (Viveros-Fauné 2012: 131). Spence (2009) concludes 'Passionate and shocking yet tightly focused this is political art at its best.'

Margolles is not alone in using corpses for artistic purposes and, indeed, may be among the most respectful. Gunther von Hagens's Körperwelten (Body Worlds) uses human bodies in a taboo-breaking ways (see, generally, Institute for Plastination 2006-2012). However, according to Konstanze Kutzbach, von Hagens's purpose is not to shock but to empower people based on the rationale that his plasticisation and exhibition of corpses represents an 'important source of power for laypersons, enabling them to better make their own decisions about medical matters' (2007: 287). The artist cannot, however, be unaware of the likelihood of his art actually shocking or being construed as prurient, whatever his stated motives. Rick Gibson's work Human Earrings is an apparent example of human material used in art, without a specific purpose beyond the technical (see Gibson 2011), but with an obvious shocking effect. This work incorporated earrings made from freeze-dried human foetuses. Both Gibson and Peter Sylverie, proprietor of the London gallery where the work was exhibited, were successfully prosecuted for outraging public decency (Lewis 2002), thereby indicating that not all taboos - albeit those formalized as law — may be broken with impunity.

Western art, particularly in the twentieth century, has commonly attacked convention and prevailing moral norms (see, generally, Hughes 1991). Breaking taboos through artistic expression can be seen as a way of rebelling against the current structures and order of society so as to re-establish identities and the regulation of aesthetics (Holden 2001: 21). Iconoclastic art, such as Marcel Duchamp's Fountain (a urinal as readymade sculpture) may, of course, invoke violent reaction or, indeed, unexpected praise (De Duve, Polan \& Rajchman 2005: 110) but is not, in the Western view, inherently dangerous to the self. Indeed, over time, the shock of such works is neutralized and they become accepted into the canon of Western art. Thus, as Jürgen Habermas observes, 'a modern work becomes a classic because it has once been authentically modern' (1998: 6) and, in Robert Hughes's words, in the field of transgressive art, '[N]othing remains unacceptable' (1991: 268). Indeed, little seems to shock contemporary New Zealand gallery goers (Burgess 2004). However, while taboo-breaking art may be offensive to 
certain members of the community, notably conservative Christians (SPCS 1999), for Māori, breach of tapu is dangerous, indeed, potentially fatal.

\section{Tapu}

Joan Metge observes that tapu is one of the words that 'have important meanings in the Māori conceptual system which are largely, if not wholly overlooked in the context of New Zealand English' (2010a: 62). Indeed, the word tapu is 'one of the most widely known though only partly understood by Pakeha' (Metge 2010b: 58). A full understanding of what tapu means to Māori is, then, elusive for Pākehā. Thus Michael Shirres observes that 'the logic behind a word which can be applied to many disparate and apparently contradictory things continues to puzzle the scholars' (1982: 29), and Anne Salmond (1978: 7) concedes that 'Maori speakers do not appear to find these associations difficult' but 'their logic has eluded scholarly analysis.' Despite these problems, the concept of taboo 'has often been a subject of anthropological inquiry since Captain Cook first used the word in his account of the Polynesians' (EvansPritchard 1967: 12). According to Franz Steiner, taboo

is concerned (1) with all the social mechanisms of obedience which have ritual significance; (2) with specific and restrictive behaviour in dangerous situations. One might say that taboo deals with the sociology of danger itself, for it is also concerned (3) with the protection of individuals who are in danger, and (4) with the protection of society from those endangered - and therefore dangerous persons. (1967: 20-21)

For Margaret Mead, the notion of tabu fundamentally relates to 'a prohibition whose infringement results in an automatic penalty' (1937: 502) but, illustrating its polysemy, Salmond observes that tapu 'can be applied equally to high descent, ritual and sacred lore, and to death, darkness, menstrual blood and filth' (1978: 7). Despite this potential uncertainty of meaning - for Pākeh $\bar{a}$, at least - Jean Smith argues that tapu is 'a single, not confused but ambivalent concept embracing both the notions of 'pure' and 'impure", (1975: 93). Metge distils anthropological observations on tapu as follows:

\footnotetext{
tapu is a condition or state of being affecting people, places, things and actions that results from association with the spiritual realm, especially the in-dwelling of mana [prestige, authority]; involves being set apart from ordinary life under ritual restriction; is dangerous unless treated respectfully according to prescribe rules; and exists in a complementary relationship with the state of noa, which provides relief and freedom from restrictions of tapu. (2010a: 65)
}

Tapu and noa, which Salmond identifies as 'unrestricted, profane' (1978: 15), 'together form an exhaustive classification: what is not tapu is noa and vice versa' (Metge 2010b: 59). Furthermore, 'Everything designated as tapu must be either avoided or handled 
with care according to prescribed rules. Breach of these rules is believed to result in sickness, trouble or even death, through the action of an offended God or spirit or as an automatic reflex' (Metge 2010b: 59). Cleve Barlow confirms that people 'who are careless in these matters then are likely to suffer some kind of affliction' and should therefore 'ensure against possible harm' (1991: 129). Breach of tapu may lead to human as well as divine sanctions; thus Raymond Firth observes that offence against tapu could lead to the offender being stripped 'of all his goods' and even being 'speared in the arm or leg into the bargain' (1959: 154).

Barlow identifies different categories of tapu and describes tapu māheuheu as a

\begin{abstract}
type of personal tapu to do with personal hygiene: sweat, bodily hair, scales, mucus, and other bodily fluids and excretions ... the personal clothing of deceased persons must be washed and treated with respect so that the living are not adversely affected by the tapu mäheuheu of the individual. If people are careless in these matters they are likely to suffer some kind of affliction. (1991: 129)
\end{abstract}

This manifestation of tapu is of critical significant in relation to dead bodies, which must be treated in particular ways (Smith 1975: 86). Hēnare, in an email observes that, for Māori, 'all things are normal as is life itself except the sensibilities around death.' Dying 'escalates the level of tapu to maximum levels' (Mead 2003: 49). Practical reasons may determine the extent to which 'controls are practiced and how observance of the traditional practice might be amended' but most Māori would not, say, take cooked food (noa) into a hospital room where a deceased person lies (tapu) (Jansen \& Jansen 2013: 48). Furthermore, as Metge observes

\footnotetext{
On leaving the cemetery, most mourners ritually cleanse themselves by washing their hands with water or bread provided in basins for the purpose. Back at the marae [meeting house], the elders lift the tapu from the place where the dead lay by reciting karakia [incantations] and consuming a token amount of food or liquor on the spot. (2010b: 263)
}

These protocols and rituals may have arisen from an ancient desire to prevent enemies from gaining psychological advantage by usurping the body parts of kin (Best 1902; Best 1926) but, for Māori, tapu, which 'comes from the gods, and embraces all the powers and influences associated with them' (Barlow 1991: 129), remains a critical concern. Here are some opinions of Māori experts on tapu in relation to So It Vanishes reported in Wellington's Dominion Post (see Dastgheib 2012: A3): 'it is inviting death in the door, more or less. I think about our children, and kids love bubbles. It would be inviting them into a situation that to children would be unsafe' (Liz Mellish, inter alia, 
natural resources adviser); '[P]eople would have inadvertently placed themselves in danger and Maori would have treated the people as being contaminated ... Maori don't muck around with issues of tapu' (Peter Adds, Head of the School of Māori Studies, Victoria University of Wellington). Consequently, Margolles's (mis)use of dead bodies, even though no more than a tincture of morgue water was involved and used with a purpose of reasserting the dignity of the dead, was not simply offensive, it was dangerous for Māori.

Following Bruno Latour, beliefs, such as tapu, should be 'given epistemic dignity if not intellectual authority' (Smith 2012: 26). Indeed, Margolles's reaction to the cancellation of her exhibition was 'one of sympathy, empathy and understanding' (Dastgheib 2012: A3). Why should it not be? The fundamental purpose of her art lies in revitalising lost taboos about death (Gallo 2006), which are, at core, concerned with group safety and human dignity. It seems unthinkable that she might seek to assert such a peculiarly Western idea as individual freedom of expression, without concern for consequences, in the face of Māori culture that persists in respecting the dead in occasionally obstinate and inconvenient ways.

\section{Cultural clashes and accommodations}

Iwi opposition to the Margolles exhibition might indicate a propensity on the part of Indigenous people for insularity and a desire to preserve their culture in aspic. Such opposition might be generalized as an antagonism between modernity and tradition but there is ample evidence to the contrary. Māori Television, for example, is the only free to air channel in New Zealand that provides access to cosmopolitan, foreign language films, and a heterogeneous contemporary Māori arts scene is well established (see, for example, Ihimaera 1996). Furthermore, as Roger Neich (2001) observes, historically Māori artistic representation of Christian imagery was adjudged to be unacceptably transgressive by Europeans. Nevertheless, the cancellation of So It Vanishes is not the first instance of a planned art exhibition being cancelled in New Zealand apparently in deference to Māori sensibilities.

\section{Treasures and pastiches}

In 1998, the Waikato Museum of Art and History cancelled Dick Frizzell's exhibition, Portrait of a Serious Artiste. Frizzell's works, which were to be displayed alongside Tainui-The Journey, a collection taonga of the local Tainui iwi, included the Four 
Square shopkeeper (a New Zealand commercial icon) with a Māori moko (facial tattoo) and tiki (charm) reinvented in European styles. The exhibition was reportedly halted because Waea Mauriohoho, a Tainui kaumātua, 'did not want it "tampering with the spiritual climate” surrounding Tainui treasures' (“Spiritual” Tampering Not Artist's Intention 1998). For Pākehā, it is, of course, a matter of conjecture whether the juxtaposition of pop-art pastiches of Māori icons against original taonga is tapu. We might speculate whether opposition was grounded in a desire to protect the integrity of the cultural treasures - an idea, it is submitted, wholly compatible with Western sensibilities and, arguably, moral rights under copyright law—or to protect museum goers from supernatural harm - an idea incompatible with Western sensibilities. No article in a code of restrictions exists that positively provides that treasure and pastiche must not be juxtaposed: that is a matter for kaumātua to decide and for outsiders to respect, without being able to enter into the closed cultural discourse. Nevertheless, an egregious lack of cultural sensitivity is indicated by expecting Tainui to, on the one hand, allow public access to their taonga and, on the other hand, have those treasures parodied under the same museum roof. Indeed, according to Mauriohoho, Frizzell chose to withdraw his exhibition after the spiritual significance of the Tainui taonga was explained to him (Te Anga 1998).

\section{Treasures and bodies}

In addition to tapu concerns, the display of human bodies as specimens, objets d'art or curios has a particular resonance for Māori, since many of their ancestors have been displayed, in whole or part, as 'artefacts' in museums around the Western world (McCarthy 2007). Consequently, museum exhibitions involving dead bodies present the prospect of cultural clashes but also indicate how accommodation can be reached. The Auckland War Museum Tamaki Paenga Hira, for example, includes an Egyptian mummy in its collection. However, local iwi, Ngati Whatua, do not object to display of the mummified body because, according to Danny Tumahai, a Ngati Whatua kaumātua and chairman of Taumata-a-iwi, an Indigenous advisory board to the museum, 'the right protocols and decisions were put in place' (McCarthy 2007).

In 2006, when the Museum of New Zealand Te Papa Tongawera ('Te Papa') planned to display the mummified body of Keku, a young woman who died some 700 BCE in Pharaonic Egypt, as centre piece of its exhibition Egypt: Beyond the Tomb, kaumatua of 
the Ngāi Tahu iwi raised concerns (Ihaka \& Stokes 2006). At the time of the Egyptian exhibition, Te Papa was also hosting Mō Tātou: Ngāi Tahu Whānui, a two-year showcase of Ngāi Tahu taonga. A display of tūpāpaku (corpses), even if mummified and ancient, would be considered, at first face, tapu. In the event, the exhibition went ahead, with Keku being displayed in a separate room 'with signage warning those offended by the display of human remains not to enter' (Ihaka \& Stokes 2006). It is understood that various precautions were undertaken to ensure the safety of the exhibition, notably ablution facilities for visitors, and that due respect was shown to her body. The protocols followed ensured that Keku was treated with the dignity due to a dead person, not simply an as exhibit, and risks for museum goers were minimised. Seddon Bennington, Te Papa's then chief executive, countered accusations of hypocrisy in displaying Keku, while seeking repatriation of Māori human remains from overseas museums, in the following terms:

\footnotetext{
The consistency of these two positions lies in our adherence to respecting the culture of origin of the human remains. Egyptian authorities, whom we have consulted extensively, feel that we are honouring their ancestors by their preservation and display, with reverence, in a public museum. Maori do not want their human remains to be displayed and we would always honour that wish. We have carefully considered how Keku can be displayed with appropriate dignity and have provided visitors with a conscious choice as to whether they view her. (2006: 4)
}

And so it seems, if appropriate processes are negotiated, dignity respected and risks minimized, Western expectations that, under certain circumstances, dead bodies may be exhibited and tapu are potentially reconcilable. Indeed, Anna Neil concludes that 'Te Papa's sustained commitment to biculturalism, demonstrated in careful consultation with iwi about all matters pertaining to Maori taonga, and in the effort to maintain Maori representation internally constitutes a real effort at partnership and a genuine act of decolonisation' (2004: 182).

\section{Korurangi: New Maori Art}

Prefiguring the So It Vanishes dispute, in 1996 the Auckland Art Gallery Toi o Tamaki hosted the exhibition Korurangi: New Maori Art. The works displayed were not traditional, indeed, artist George Hubbard characterized himself and his fellow Korurangi exhibiters as 'outcasts and misfits,' 'detribalised and dysfunctional,' with broken whakapapa (genealogy) (cited by Brunt 2004: 239). This is a significant assertion since, as Hirini Moko Mead advises, pümanawa (creative talent) in the traditional view 'comes to the individual through the parents and down through one's 
ancestry ... Whakapapa determines the distributions of talents' (2003: 254-55). Certainly tensions between traditional and modern Māori artists were evident at the time of Korurangi (Mead 1993: 4); nevertheless, the gallery sought to incorporate certain traditional protocols into this exhibition of contemporary Indigenous art. But it did so unsuccessfully. In a reflective essay, Alexa Johnston, the gallery's chief curator at that time, describes 'a deeply distressing cultural faux pas and the cause of great tension for those who attended' when, in a basic failure to honour manaakitanga (hospitality), food for sharing was not provided after a blessing of the exhibition (1996: 9). However, far more significant than a 'cultural faux pas,' in an egregious breach of tapu, an exhibition space adjacent to Korurangi was planned to host Julia Morison's Ten "Monochromes" (also referred to as $1, \mathrm{mOnOchrOmes),} \mathrm{an} \mathrm{alchemy-inspired} \mathrm{project} \mathrm{that} \mathrm{included} \mathrm{blood}$ and excrement as its basest elements. Morison agreed to removal of the offending items 'but was distressed and angered by the perceived downgrading of her work. She asked that $1, \mathrm{mOnOchrOmes}$ not be available for viewing until it had its own separate viewing a week later' (Johnston 1996: 9). Parallel with Morison's exhibit breaching of tapu, Diane Prince's installation for Korurangi, Flagging the Future, included a prostrate New Zealand flag on which viewers were invited to step. This element of her work was considered illegal and both the gallery and Prince were threatened with prosecution under the Flags, Emblems, and Names Protection Act 1981. Whether or not prosecution was likely to lead to conviction, given New Zealand's robust freedom of expression jurisprudence, 'after considerable consultation,' the flag was removed, an act which led to accusations of 'cowardly censorship by the Gallery' (Johnston 1996: 9). Johnston concludes that the crises 'prompted an institutional shift in attitude and ways of doing things' (1996: 11).

Conal McCarthy cautions that 'one size does not fit all-solutions to problems are specific to local conditions and it is difficult to generalise and apply these to other situations' (2011: 246); nevertheless the lessons of Korurangi were both relevant to So It Vanishes and well-known in curatorial circles, but they seem to have gone unheeded. ${ }^{7}$ Local art commentator Mark Amery concludes '[G]iven its disturbance of Maori

\footnotetext{
${ }^{7}$ Has The Dowse deliberately courted controversy? In August 2012, the museum hosted the world premiere of Sophia Al-Maria's Cinderazahd: For Your Eyes Only, a video depicting women without hijabs or veils preparing for a wedding. Compliance with the artist's wish that men should not be allowed to view the video prompted 'outrage from locals' and complaints to the Human Rights Commission (Hunt 2012: A5).
} 
tikanga [custom] and that the Dowse is guardian of this pataka, [cancellation] was the only course of action' but adds '[T] hat processes didn't see this come to a head earlier is regrettable' (2012: 11). McCracken (2012) says that The Dowse had 'been in close consultation' with Te Atiawa 'in the months leading up to the opening' of the exhibition. However, in the light of the Korurangi precedent, the apparent assumption on the part of The Dowse that a kaumātua might routinely bless an exhibition that could endanger people's health and lives was, in the kindest interpretation, naïve; but it also acted to allow $i w i$ intransigence to be implied. Reflecting on Korurangi, Johnston says 'another appropriate move would have been to discuss the issues with the kaumatua and ask them directly to make the decision' (1996: 9). But this would effectively make the kaumātua a censor - an unenviable and unnecessary role if protocols are in place that incorporate Māori beliefs.

\section{Un-sharable spaces}

Contrasting Māori approaches to death with the Mexican José Guadalupe Posada's satirical calavera (skull) cartoons, arts commentator Hamish Keith observed that with the cancellation of So It Vanishes 'a chance seems to have been lost to explore that other [Mexican] view of death' (2012: 43). An exercise in comparative anthropology might, indeed, be interesting but the extent to which Margolles's work represents a typical Mexican approach to corpses is far from obvious. Keith further argues, '[I]f art museums are not places to safely explore that, then it would be hard to think where else might be' (2012: 43). However, as Amery observes, taonga, such as the sacred pätaka, do not belong in a contemporary arts space, consequently the expectation that public exhibition spaces should play 'multiple cultural roles can place limits on having valuable safe spaces that allow work by artists such as Margolles to challenge our thinking' (2012: 11). Conversely, galleries may be inappropriate places to exhibit the work of certain contemporary Māori artists. Thus, supporting his translation of tapu, John Macalister cites an interview from City Voice: 'Maori artists consider their art tapu and do want to have food or drink consumed nearby, or displayed near work for sale' (2005: 126).

It is a matter of counterfactual speculation whether or not So It Vanishes would have been cancelled had it not been for the proximity of the sacred pātaka. Frizzell's Portrait of a Serious Artiste was cancelled in Hamilton but exhibited at the Wellington City 
Gallery (Swain 1997). Moreover, his playful (but affectionate) adoptions of Māori imagery are widely available in New Zealand: for example, a sequence portraying a cartoon 'Mickey Mouse' changing in stages to a 'Maori Tiki' is a bestselling print (Mickey to Tiki by Dick Frizzell Mens Tee 2008). ${ }^{8}$ Mummified bodies have been exhibited in leading museums and transgressive artworks can be found in New Zealand's regional art galleries, such as the Govett-Brewster Contemporary Art Museum in provincial New Plymouth. It seems unlikely, then, that an exhibition of Margolles's work in a private Wellington art gallery would have attracted $i w i$ action, particularly as Pākehā are believed to be immune to the risks of breaching tapu (Mead 2003: 49). Mellish noted that 'iwi would have been unhappy at the installation being shown in any gallery, but there was greater concern because of possible contamination of the pataka' (cited Dastgheib 2012: A3, emphasis added).

While Māori and Pākehā may generally share public spaces with a degree of harmony, some places are not suitable for sharing at all times. Consequently, institutions, such as The Dowse, face considerable difficulties in meeting the occasionally conflicting demand for cosmopolitan exhibitions and the duty to maintain the integrity of Indigenous treasures. As Jim and Mary Barr observe

\begin{abstract}
What has complicated the situation for the Dowse is the question of its identity. Originally called the Dowse Art Gallery in the 1970s, it veered into the territory of community museum in the 1980s expanding its commitment to local taonga by taking in Nuku Tewhatewha. Now it is struggling to redevelop its role as a contemporary art museum. All these different identities and expectations make for contradictions as well as conflicts. (2012)
\end{abstract}

Indeed, the identifier 'Art Museum' - optatively both, yet, in fact, neither quite museum nor gallery - indicates the problem. The art gallery as a haven of free expression that greatly lies beyond public censure and state censorship holds a special place in the modern imagination. As Stuart Culver argues, 'anything is art if it is found in an art gallery, and an art gallery is wherever art lovers gather to respond aesthetically to objects' (1994: 151). In contrast, the multi-functional 'art museum' is not a space that taboo-breaking art might easily share with another culture's treasures or challenge its beliefs.

\footnotetext{
${ }^{8}$ Since New Zealand copyright law does not protect pastiche, or, indeed, traditional Indigenous artwork, we might wonder whether the artist is at greater risk of the Disney Corporation asserting its intellectual property rights than Māori seeking to protect their taonga.
} 


\section{Conclusion}

This article has sketched the cancellation of So It Vanishes and indicated the difficulties of juxtaposing transgressive art and Indigenous treasures, although it appears that Māori concerns principally related to the risk to people, not to things. If Margolles's artistic aim with So It Vanishes was to revitalize attenuated taboos about corpses, then, ironically, it was found that tapu remains potent in Aotearoa New Zealand. The response to the cancellation of the exhibition has generally been muted, perhaps because it happened at the periphery of the noisy and busy International Arts Festival.

Nevertheless, those interested in contemporary art were denied the rare opportunity to engage with the compelling but challenging work of an important artist. But it would be wrong to characterize the cancellation as a victory for Indigenous over cosmopolitan values. The establishment of protocols for bi-cultural involvement by major museums and galleries has permitted solutions to ostensibly intractable problems to be solved; nevertheless a simple, but unavoidable, conclusion can be drawn from the Margolles affair and that is circumstances may arise when certain important spaces should not be shared.

\section{Acknowledgements}

A note of thanks to the reviewers, and to Ërima Hēnare who advised on Maori concepts and translations.

\section{Reference list}

Amery, M. 2012, 'Matters of Life and Death,' The Dominion Post, Arts \& Entertainment, 1 March: 1.

Barlow, C. 1991, Tikanga Whakaaro: Key Concepts in Māori Culture. Oxford University Press, Auckland.

Barr, J. \& Barr, M. 2012, 'Soap and Water,' Over the Net. Online, available: from: http://www.overthenet.blogspot.co.nz/2012/02/soap-and-water.html (Accessed 9 April 2013).

Bell, A. 2011, 'The History of The Dowse,' EyeContact. Online, available: http://eyecontactsite.com/2011/07/the-history-of-the-dowse (Accessed 8 April 2012).

Best, E. 1902, 'Notes on the Art of War as Conducted by the Maori of New Zealand, with Accounts of Various Customs, Rites, Superstitions, etc Pertaining to War, as Practised and Believed in by the Ancient Maori,' Journal of the Polynesian Society, vol. 11, no. 2: 47-75.

Best, E. 1916, 2005, Maori Storehouses and Kindred Structures: Houses, Platforms, Racks and Pits Used for Storing Food, etc. Te Papa Press, Wellington.

Best, E. 1926, 'Notes on Customs, Ritual and Beliefs Pertaining to Sickness, Death, Burial and Exhumation among the Maori of New Zealand,' Journal of the Polynesian Society, vol. 35, no. 137: 6-30.

Bennington, S. 2006, 'How Te Papa Honours the Dead,' The Dominion Post, 27 December: 4.

Brunt, A. 2004, 'Since 'Choice!': Exhibiting the 'New Maori Art,' in On Display: New Essays in Cultural Studies, (eds) A. Smith \& L. Wevers. Victoria University Press, Wellington: 215-42.

Burgess, M. 2004, 'Intrigued by the Shock Art of the Few,' The New Zealand Herald, 19 May. Online, available: http://www.nzherald.co.nz/lifestyle/news/article.cfm?c id=6\&objectid $=3567178$ (Accessed 9 April 2012). 
Cave, D. 2012, 'Toll of Mexican Crime Wave, Written in Faces on the Wall,' The New York Times, 22 March: A6.

Coulson, A. 2004, 'Teresa Margolles, Museum für Moderne Kunst, Frankfurt, Germany,' Frieze, no. 85. Online, available: http://www.frieze.com/issue/review/teresa margolles/ (Accessed 1 March 2012).

Culver, S. 1994, 'Whistler v. Ruskin: The Courts, the Public and Modern Art,' in Administration of Aesthetics: Censorship, Political Criticism, and the Public Sphere, (ed.) R. Burt. University of Minnesota Press, Minneapolis, MN: 149-67.

Dastgheib, S. 2012, 'Exhibition Cancelled after Iwi Object to Content,' The Dominion Post, 24 February: A3.

De Duve, T., Polan, D. \& Rajchman, J. 2005, Pictorial Nominalism: On Marcel Duchamp's Passage from Painting to the Readymade. University of Minnesota Press, Minneapolis, MN.

Evans-Pritchard, E. 1967, 'Preface,' in Taboo, F. Steiner, Penguin Books, Harmondsworth, 11-13.

Finnis, J. 1980, Natural Law and Natural Rights, Clarendon Press, Oxford.

Firth, R. 1959, Economics of the New Zealand Maori, $2^{\text {nd }}$ ed. R. E. Owen, Wellington.

Gallo, R. 2006, New Tendencies in Mexican Art: The 1990's. Palgrave Macmillan, New York.

Gibson, R. 2011, 'Freeze-dried Sculptures,' rickgibson.net. Online, available: http://www.rickgibson.net/freezedry.html (Accessed 21 March 2012).

Habermas, J. 1998, 'Modernity: An Incomplete Project,' in The Anti-Aesthetic: Essay on Postmodern Culture, (ed.) H. Foster. The New Press, New York: 3-15.

Holden, L. 2001, 'Taboo: Structure and Rebellion,' The Institute for Cultural Research. Online, available: http://www.i-c-r.org.uk/publications/monographarchive/Monograph41.pdf (Accessed 1 March 2012).

Hooper, G. 2007, 'Dark Currents,' RealTime, no. 82. Online, available: http://www.realtimearts.net/article/82/8801 (Accessed 6 April 2013).

Hughes, R. 1991, The Shock of the New: Art and the Century of Change. Thames \& Hudson, London.

Hunt, E. 2012, 'Muslim Exhibition for Your Eyes Only If You're a Woman,' Sunday Star-Times, 26 August: A5.

Hutt City Council 2007, Demographic Profile of the City of Lower Hutt. Hutt City Council, Lower Hutt.

Hutt City Council 2011, Hutt City Annual Report 2010-11. Hutt City Council, Lower Hutt.

Ihaka, J. \& Stokes, J. 2006, 'Talks Avoid Disrespect to Egyptian Mummy,' The New Zealand Herald, 6 December: Online, available: http://www.nzherald.co.nz/history/news/article.cfm?c id=500832\&objectid=10413985 (Accessed 27 March 2012).

Ihimaera, W. 1996, Mataora: The Living Face: Contemporary Maori Art. David Bateman, Auckland. Institute for Plastination 2006-2012, 'Gunther von Hagens' Body Worlds: The Original Exhibitions of Human Bodies,' Body Worlds. Online, available: http://www.bodyworlds.com/en/prelude.html (Accessed 1 March 2012).

Jansen, P. \& Jansen, D. 2013, 'Māori and Health,' in Cole's Medical Practice in New Zealand, $12^{\text {th }}$ ed, (ed.) I. St George. Medical Council of New Zealand, Wellington: 52-64.

Johnston, A. 1996, 'The Pathway to Korurangi: New Maori Art,' in Korurangi: New Maori Art, (ed) C. Szekely, Auckland Art Gallery Toi o Tamaki, Auckland: 7-11.

Keith, H. 2012, 'Bursting Death's Bubble,' New Zealand Listener vol. 232: 43.

Kutzbach, K. 2007, The Abject of Desire: The Aestheticization of the Unaesthetic in Contemporary Literature and Culture. Rodopi, Amsterdam.

Lewis, T. 2002, 'Human Earrings, Human Rights and Public Decency,' Entertainment Law, vol.1, no. 2: 50-71

Macalister, J. 2005, A Dictionary of Māori Words in New Zealand English. Oxford University Press, Melbourne.

McCarthy, C. 2007, Exhibiting Māori: A History of Colonial Cultures of Display. Berg, Oxford. 2011, Museums and Māori: Heritage Professionals, Indigenous Collections, Current Practice. Te Papa Press, Wellington.

Maclean, C. 2012, 'Wellington Places-Hutt Valley-South,' Te Ara-the Encyclopedia of New Zealand. Online, available: http://www.TeAra.govt.nz/en/wellington-places/page-8 (Accessed 9 April 2013).

McCracken, C. 2012, 'Teresa Margolles - So It Vanishes,' 26 February (Media release).

Mead, H. M. 1996, 'Maori Art Restructured, Reorganised, Re-examined and Reclaimed,' He Pukenga Korero: Journal of Maori Studies, vol. 2, no. 1: 1-7. 2003, Tikanga Māori: Living by Māori Values. Huia, Wellington.

Mead, M. 1937, 'Tabu,' in Encyclopaedia of the Social Sciences, vol. 7, (ed.) E. R. A. Seligman. Macmillan, London: 502-5. 
Metge, J. 2010a, Tuamaka: the Challenge of Difference in Aotearoa New Zealand. Auckland University Press, Auckland. 2010b, Rautahi: the Maori of New Zealand. Routledge, London.

'Mickey to Tiki by Dick Frizzell Mens Tee' 2008, GlobalCulture. Online, available: http://www.globalculture.co.nz/catalogue/mens/short-sleeve-tees/mickey-to-tiki-menstee/1114/product.aspx (Accessed 16 March 2012).

Neich, R. 1996, 'Wood-carving,' in Maori: Art and Culture, (ed) D. Starzecka. David Bateman, Auckland: 69-113. 2001, Carved Histories: Rotorua Ngāti Tarawhai Woodcarving. Auckland University Press, Auckland.

Neil, A. 2004, 'National Culture and the New Museology,' in On Display: New Essays in Cultural Studies, (eds) A. Smith \& L. Wevers. Victoria University Press, Wellington, 180-96.

Nungesser, M. 2007, 'Teresa Margolles Sierra,' Culturebase.net: The International Artist Database. Online, available: http://www.culturebase.net/artist.php?1013 (Accessed 1 March 2012).

Ryan, P. M. 2008, The Raupō Dictionary of Modern Māori, $2^{\text {nd }}$ ed. Penguin, North Shore, New Zealand.

Salmond, A. 1978, 'Te Ao Tawhito: A Semantic Approach to the Traditional Maori Cosmos,' Journal of the Polynesian Society, vol. 87, no. 1: 5-28.

Scott Bray, R. 2011, 'Teresa Margolles's Crime Scene Aesthetics,' South Atlantic Quarterly, vol. 110, no. 5: 933-48.

Shirres, M. P. 1982, 'Tapu,' Journal of the Polynesian Society, vol. 91, no. 1: 29-52.

Simpson, J. \& Weiner, E. 1989, Oxford English Dictionary $\left(2^{\text {nd }}\right.$ ed $)$ vol. XVII, Clarendon Press, Oxford.

Smith, B. 2012, 'Dolls, Demons and DNA,' London Review of Books, vol. 34, no. 5: 25-26.

Smith, J. 1975, 'Memoir No 40: Tapu Removal in Maori Religion,' Journal of the Polynesian Society, vol. 84: 43-96.

Society for the Promotion of Community Standards Inc (SPCS) 1999, 'A Retrospective: The "Virgin in a Condom” Controversy,' SPCS. Online, available: http://spcs.org.nz/wpcontent/uploads/ResearchReports/VirginInACondom.pdf (Accessed 3 March 2012).

Sorensen, R. 2007, 'Bubbles an Art Beat from Death,' The Australian Local, 6 August: 5.

Spence, R. 2009, 'Martin Boyce/Teresa Margolles, Venice Bienalle,' Financial Times, 19 August. Online, available: http://www.ft.com/intl/cms/s/0/361e545c-8cde-11de-a540-00144feabdc0.html (Accessed 15 March 2012).

“"Spiritual” Tampering Not Artist's Intention' 1998, The Evening Post, 6 February: 3.

Steiner, F. 1967, Taboo. Penguin Books, Harmondsworth.

Stephenson, K. 2012, 'What's on at ... The Dowse,' Friends of the Dowse, no. 36: 4.

Swain, P. (1997, March $8^{\text {th }}$ ), 'Frizzell Month Shows Us Work by 'A Serious Artiste,' The Dominion: 24.

Te Anga, N. 1998, 'Exhibition Wasn’t Banned: Kaumatua,' Waikato Times, 10 February: 1.

Te Awekotuku, N. 1996, 'Maori: People and culture,' in (ed.) D. Starzecka, Maori: Art and Culture. David Bateman, Auckland: 26-49.

The Dowse Art Museum. 2010. 'Our History,' The Dowse Art Museum. Online, available: http://www.dowse.org.nz/en/Visit/Visiting-The-Dowse/History-and-Culture/ (Accessed 1 March 2012).

The Dowse Art Museum. 2011, 'Teresa Margolles' Delicate Dealings with Death at The Dowse,' 12 December (Media release). 2012, 'The Dowse Art Museum Season 1,' (Brochure).

Viveros-Fauné, C. 2012, 'The New Realism,' Art in America, vol. 100: 126-32.

Williams, H. W. 1992, A Dictionary of the Maori Language, $7^{\text {th }}$ ed. GP Publications, Wellington. 